University of Nebraska - Lincoln

DigitalCommons@University of Nebraska - Lincoln

Making Contact: Rooting Out the Potential for Exposure of Commercial Production Swine Facilities to Feral Swine in North Carolina

Richard M. Engeman

USDA-APHIS-Wildlife Services, s_r100@yahoo.com

Carl Betsill

USDA/APHIS/Wildlife Services

Tom Ray

NCDA \& CS, Veterinary Division

Follow this and additional works at: https://digitalcommons.unl.edu/icwdm_usdanwrc

Engeman, Richard M.; Betsill, Carl; and Ray, Tom, "Making Contact: Rooting Out the Potential for Exposure of Commercial Production Swine Facilities to Feral Swine in North Carolina" (2011). USDA National Wildlife Research Center - Staff Publications. 1305.

https://digitalcommons.unl.edu/icwdm_usdanwrc/1305

This Article is brought to you for free and open access by the U.S. Department of Agriculture: Animal and Plant Health Inspection Service at DigitalCommons@University of Nebraska - Lincoln. It has been accepted for inclusion in USDA National Wildlife Research Center - Staff Publications by an authorized administrator of DigitalCommons@University of Nebraska - Lincoln. 
This article is a U.S. government work, and is not subject to copyright in the United States.

\title{
Making Contact: Rooting Out the Potential for Exposure of Commercial Production Swine Facilities to Feral Swine in North Carolina
}

\author{
Richard Engeman, ${ }^{1}$ Carl Betsill, ${ }^{2}$ and Tom Ray ${ }^{3}$ \\ ${ }^{1}$ National Wildife Research Center, 4101 LaPorte Avenue, Fort Collins, CO 80521 \\ ${ }^{2}$ USDA/APHIS/Wildlife Services, 6213-E Angus Dr., Raleigh, NC 27617 \\ ${ }^{3}$ NCDA \& CS, Veterinary Division, 2 W Edenton St., 1030 Mail Service Center, Raleigh, NC 27699
}

\begin{abstract}
Despite North Carolina's long history with feral swine, populations were low or absent in eastern counties until the 1990s. Feral swine populations have since grown in these counties which also contain a high density of commercial production swine (CPS) facilities. Sixteen of the highest swine producing U.S. counties also populated with feral swine are in North Carolina. Disconcertingly, since 2009, positive tests for exposure to swine brucellosis or pseudorabies virus have been found for feral swine. We surveyed 120 CSP facilities across four eastern counties to document the level and perception of feral swine activity around CSP facilities and to identify disease transmission potential to commercial stock. Nearly all facility operators (97\%) recognized feral swine were in their counties. Far fewer said they had feral swine activity nearby (18\%). Our inspections found higher presence than perceived with feral swine sign at 19\% of facilities where operators said they had never observed feral swine or their sign. Nearly $90 \%$ expressed concern about feral to domestic disease transmission, yet only two facilities had grain bins or feeders fenced against wildlife access. Due to increasing feral swine populations, recent evidence of disease in feral populations, the importance of swine production to North Carolina's economy and the national pork industry, and potential for feral-domestic contact, we believe feral swine pose an increasing disease transmission threat warranting a stringent look at biosecurity and feral swine management at North Carolina CPS facilities.
\end{abstract}

Key words: disease exposure, feral hog, invasive species, pork production, pseudorabies, swine brucellosis

\section{INTRODUCTION}

Swine have a long history in North Carolina with the first introduction by the Spanish as early as 1526 (Brockington and Hurley, 2006). By the early part of the eighteenth century, North Carolina was said to have the highest

Published online: May 20, 2011

Correspondence to: Richard Engeman, e-mail: Richard.m.engeman@aphis.usda.gov population of feral swine of any colony (Brickel, 1737). The coastal plain in particular was impacted ecologically with almost no longleaf pine regeneration as a result of feral swine foraging (Frost, 1993). However, in 1883, North Carolina enacted its first law to forbid livestock to "run at large" (N.C. General Statute Chapter 68-16), which apparently helped lead to population decreases. By the mid-1970s, Wood and Barrett (1979) reported only five western North Carolina counties with stable feral swine 
populations. One small additional population in eastern North Carolina, along the Neuse River in Johnston County, was known to local wildlife biologists working that area, but the remainder of the coastal plain was remarkably absent of feral swine (J.S. Osborne, North Carolina Wildlife Resources Commission, retired, personal communication). The century-long tradition of prohibiting free-ranging livestock may have been a contributing factor to the lack of feral populations.

Beginning in the early 1990s, changes in bear hunting regulations in the coastal plain also brought about an interest in feral swine hunting. Dogs are typically used to hunt both bear and feral swine. With the introduction of hunting with dogs in eastern North Carolina, deer clubs began stocking swine to "have something to hunt" after deer season. Increasing enthusiasm for hunting feral swine was reflected and reinforced by its popularity in many sporting magazines, and an avalanche of swine releases ensued (which we corroborated through discussions with numerous coastal deer clubs and hunters). Further contributions to the feral populations in the 1990s may have resulted from damage to swine facilities by Hurricane Fran. However, we have observed most feral swine to have few phenotypic traits of domestic blood lines, unlike other areas of the country where feral populations resulted from domestic escapes.

Increasing feral swine populations have increased concern among eastern North Carolina swine growers about potential disease transmission from feral to domestic populations. Pseudorabies virus (PRV) had been eradicated in all U.S. domestic swine populations by 2004 (USAHA, 2004; USDA/APHIS, 2007a), and swine brucellosis (SB) had been eradicated from domestic swine in all states but Texas by 2007 (USDA/APHIS, 2007b). However, feral populations threaten disease reintroduction to domestic populations (Feral Swine Subcommittee on Brucellosis and Pseudorabies 2005). Only recently has exposure to PRV and SB been detected in feral swine in North Carolina, with 10 positive for exposure to $\mathrm{SB}$ and 2 positive for exposure to PRV discovered in 2009 and 2010 (USDA/APHIS Wildlife Disease Program, unpublished data; NCDA \&CS, unpublished data). Moreover, North Carolina feral swine showed exposure to swine influenza viruses (SIV) commonly associated with commercial production swine (CPS) facilities, raising concern whether such facilities have adequate biosecurity to prevent disease exchange between feral and commercial animals (Corn et al., 2009). Corn et al. (2005) reported that 16 of the highest ranked swine pro- ducing counties in the US also populated with feral swine were in North Carolina, including 8 out of the top 10. The same report highlighted the implications for disease spread resulting from expanding feral swine populations.

In 2008, the North Carolina Department of Agriculture and Consumer Services in cooperation with the US Department of Agriculture, Animal and Plant Health Inspection Service, Wildlife Services conducted surveys of CPS facility operators, including site inspections around their facilities, in order to determine perceived and actual feral swine activity in the immediate vicinity of commercial swine operations. We present those results here and comment on their implications.

\section{Methods}

\section{Study Area}

North Carolina Department of Agriculture and Consumer Services (NCDA) field veterinarians and animal health technicians were presented with feral swine range maps provided by the Southeastern Cooperative Wildlife Disease Study (SCWDS) and asked to identify four counties in North Carolina with high numbers of CPS operations in two different catchment areas. Johnston and Wayne were selected in the Neuse River basin and Duplin and Sampson counties were selected in the Cape Fear basin. From NCDA's list of swine facilities in these counties, 50 CPS operations were randomly selected in each county. Interviews were conducted with farm operators in order to gain permission for access. This process was continued until 30 sites were selected in each of the four counties. All interviews were conducted by local NCDA personnel.

\section{CPS Survey}

On-site farm operators were questioned about their knowledge and awareness of feral swine near the commercial operation, biosecurity measures in place, and concerns about potential damage from feral swine. Survey questions are given with the results in Table 1. Following the interview, the interviewer made a physical inspection of the area within $300 \mathrm{~m}$ of any swine holding facility on the operation. The inspections followed all biosecurity measures of the growers including disposable boots and scheduling visits so as not to cross contaminate farms. The interviewers searched for feral swine sign (e.g., prints, wallows, scat) and wildlife tracks or trails near grain bins, 


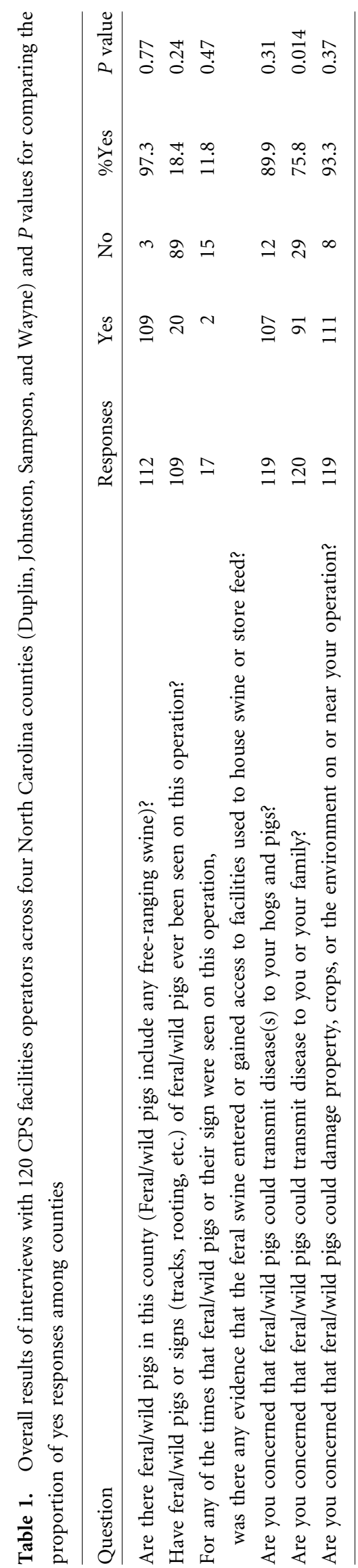

and other infrastructure. They also noted whether grain bins were fenced to prevent wild animal access. To insure consistency, each NCDA interviewer had been trained by USDA/Wildlife Services to recognize feral swine sign. The proportions of CPS facilities where operators had answered yes to a question were compared between counties using Pearson's $\chi^{2}$ or Fisher's "exact" test, depending on cell frequencies in the contingency table.

Trail cameras were used at each facility to provide an instantaneous indice of feral swine and other wildlife activity in the immediate vicinities of the CPS facilities. This process was carried out during two seasons: Aug 08 and Feb 09. During the initial season, 40 trail cameras were placed at 10 CPS facilities at a time in each of the four counties, where they were left for 4 days and then moved to another 10 sites until all 30 sites in each county were monitored. Trailscout ${ }^{\circledR}$ (Bushnell Outdoor Products, Overland Park, KS) cameras were used and positioned along, rather than across, trails or corridors to maximize the probability of photo capture. Due to moisture problems related to weather events, we switched to Scout Guard ${ }^{\circledR}$ Model SG550 (HCO, Norcross, GA) with similar specifications and settings for the February field season. The number of cameras was increased to 15 in each county, which were stationed for 10 consecutive days before moving.

\section{Results}

Results of interviews conducted with the local farm operator at each of the 30 modern CPS facilities in each of the four counties are shown in Table 1. Responses to the survey questions were fairly consistent across the four counties, with the proportion of "yes" responses statistically indistinguishable for 6 of the 7 questions. Nearly all operations (109 of 112 responses, 97.3\%) recognized the presence of feral swine in their county, but only 20 of those 109 responses (18.4\%) identified feral swine presence near their particular facilities. Of those having observed feral swine or sign at their facilities, only $11.8 \%$ (2 of 17) had observed that feral swine had been in contact with the domestic animals or their feed. Nevertheless, a high proportion (107 of 119 responses, $89.9 \%$ ) of respondents expressed concern that feral swine could transmit diseases to their domestic stock. Positive response rates diverged among counties as to the level of concern for disease transmission to humans $\left(\chi^{2}, \mathrm{df}=3, P=0.014\right)$. Operators in Johnston (18 of 30 , 
$60.0 \%$ ) and Sampson (20 of 30, 66.7\%) expressed similar, but lower concern than operators in Wayne (26 of 30, $86.7 \%$ ) and Duplin (27 of 30, 90.0\%) counties. A very high proportion $(93.3 \%)$ of operators across counties were concerned that feral swine would damage their property or environment.

The replies demonstrate a consistent awareness geographically of the presence of feral swine across the four counties and vulnerability to the potential problems they could cause. However, they were not always aware of the proximity of feral swine to their particular facility. In inspections around the facilities, NCDA personnel observed feral swine sign on 19\% (17 of 89) of the properties where the operator had indicated they had never observed feral swine or their sign. This clearly demonstrated that feral swine presence is higher than observed by the operators. Only two of the facilities inspected (1.7\%) had fenced all grain bins or feeders to prohibit access by mid to large size terrestrial wildlife. Game trails or wild animal tracks leading to feeders or grain bins were observed on 10 facilities $(8.3 \%)$. Feral swine tracks or other sign were observed within $300 \mathrm{~m}$ of 29 of the facilities (24.2\%).

Camera results reflected the patchy and seasonal nature reportedly characterizing feral swine contact with CPS facilities. During the August 2008 "snapshot" of instantaneous activity, feral swine were photographed in the vicinities of two facilities. Unfortunately, we cannot say what the instantaneous picture was across the facilities due to systematic camera failures. These defects resulted in disappointing results for the camera portion of this study. Fourteen of the 50 total cameras (28\%) failed to operate on occasion during the study period (replacement cameras were installed as needed to maintain 40 cameras active simultaneously across the four counties). Other cameras failed to take night photos reliably while many day-time pictures were of extremely poor quality. During the February survey, no swine were photographed. However, during both camera surveys, deer were shown to have a high incidence of contact with facility properties ranging from an average of 0.32 deer per day per facility in Sampson County to 0.74 deer per day per facility in Duplin County.

\section{Discussion}

The interviews and field inspections showed feral swine to be frequently in the immediate vicinity of commercial swine houses. Feral swine tracks as well as those of other

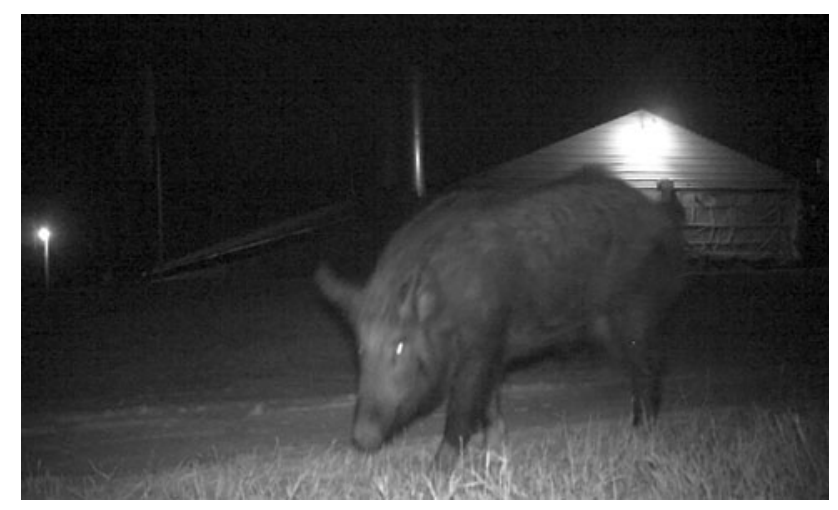

Figure 1. Photograph of a feral swine returning from foraging at the base of a grain bin at a CPS operation in North Carolina

wildlife are commonly seen where they had been feeding on spilled feed at the base of grain storage where feed is augured directly into the facility (see Fig. 1). These grain bins are often placed near vent fans at the ends of the swine houses. Any airborne disease such as SIV as reported by Corn et al. (2009) could potentially be spread through this arrangement, implying other diseases, such as PRV, could spread via airborne transmission from feral to domestic animals (Gloster et al., 1984; Kristensen et al., 2004). Additionally, the sides of the swine houses are screened but nose to nose contact may still be possible. Feral swine can transmit disease via contact between animals, contaminated substances, and airborne routes (Schoenbaum et al., 1991; Hahn et al., 1997; Gloster et al., 1984; Kristensen et al., 2004). For example, a feral boar attracted to a feed bin may also have contact with domestic animals through facility screening in an attempt to gain access to sows.

States such as South Carolina with exposure rates to SB and PRV of 14 and 20\%, respectively, in wild swine (Corn et al., 2009) illustrate, it is likely only a matter of time before higher exposure rates are seen in North Carolina. Locally, it is common knowledge that feral swine are brought into North Carolina from South Carolina to stock for hunting. Data collected opportunistically in 2009 and 2010 has shown nine positive SB titer levels in serum from Johnston County and one positive from Bladen County (USDA/APHIS Wildlife Disease Program, unpublished data), and two positive for PRV from Sampson County (NCDA \&CS, unpublished data).

Domestic swine provided the second leading source of gross farm income in 2007 in North Carolina, with the combined effects of pork production, packing, and processing estimated at over $\$ 7.2$ billion in sales, $\$ 2.25$ billion in value-added income and 46,657 jobs (NPPC, 2009). PRV 
or SB outbreaks in commercial swine herds could cause the industry to lose $80 \%$ of its value and take 5 years to recover (Dr. Tom Ray, NCDA \& CS, personal communication). North Carolina also exports approximately 10,000 feeder pigs per day to 17 other states (Dr. Tom Ray, NCDA \& CS, personal communication). Thus, the loss of North Carolina PRV or SB free status could have significant consequences to the commercial swine industry, both within North Carolina and nationwide.

Given the increasing and expanding feral swine populations in eastern North Carolina, the recently detected evidence of disease in the feral populations, the evidence of feral swine presence near commercial facilities, and the importance of commercial swine production to the North Carolina economy and to the national pork industry, we believe feral swine pose a real and increasing threat for disease transmission warranting a more stringent look at biosecurity and feral swine management at North Carolina CPS facilities. That we also found a high incidence of deer in proximity of CPS facilities is primarily a concern should diseases such as bovine tuberculosis or foot-and-mouth disease virus be introduced to the area. CPS operators consistently recognized the threat from feral swine with over $90 \%$ in our survey both acknowledging feral swine presence in their county and expressing concern about disease transmission to domestic stock. Even so, our results still demonstrated the actual presence of feral swine at CPS facilities exceeds the perception by facility operators. The prospect of disease transmission from feral swine to humans probably seemed a less immediate possibility than transmission to domestic stock, which likely accounts for the variability without pattern among the counties in levels of concern (60-90\%). Existing biosecurity measures coupled with small and disease-free (until recently) feral populations have been adequate in maintaining North Carolina's disease-free status to date, but increasing feral swine populations and their exposure to disease could threaten the status quo.

Two general approaches exist for reducing the risk of disease transmission from feral to domestic swine. One is to create more secure barriers between feral swine and domestic stock and their food and water resources. Communication of the need, designs, and implementation methods could be disseminated through means such as extension programs. Complementing increased biosecurity, the other management strategy is to reduce populations of feral swine in areas around CPS facilities. Considering the density of these facilities in eastern North Carolina, regional swine control would likely be the most costefficient means to achieve population reductions. Trapping is the most feasible control tool for this agrarian landscape and has been shown to be effective for reducing swine populations over a wide area (e.g., Engeman et al., 2007).

Our findings have illuminated a developing problem in eastern North Carolina that could have national consequences. They also draw attention to information needs. Because PRV and SB both appear to now be found in feral swine, closer monitoring of feral swine diseases in areas with CPS facilities would help prioritize management actions against feral swine and define any urgent needs for operators to improve biosecurity. Efficient and effective means to communicate the current situation to operators and encourage biosecurity improvements are also needed. Another great concern is the increasing interest in pasture pork in North Carolina. The risk of exposure to feral swine is much higher using this technique of confinement with few practical ways of increasing biosecurity other than feral swine control programs.

\section{REFERENCES}

Brickel J (1737) The Natural History of North Carolina, Dublin: James Carson

Brockington L, Hurley SL (2006) Plantation Between the Waters: A Brief History of Hobcaw Barony, Charleston, SC: The History Press

Corn JL, Cumbee JC, Chandler BA, Stallknecht DE, Fischer JR (2005) Implications of feral swine expansion: expansion of feral swine in the United States and potential implications for domestic swine. Proceedings of the United States Animal Health Association 109:295-297

Corn JL, Cumbee JC, Barfoot R, Erickson GA (2009) Pathogen exposure in feral swine populations geographically associated with high densities of transitional swine premises and commercial swine production. Journal of Wildlife Diseases 43:713721

Engeman RM, Stevens A, Allen J, Dunlap J, Daniel M, Teague D, Constantin BU (2007) Feral swine management for conservation of an imperiled wetland habitat: Florida's vanishing seepage slopes. Biological Conservation 134:440-446

Feral Swine Subcommittee on Brucellosis and Pseudorabies (2005) Feral Swine Subcommittee on Brucellosis and Pseudorabies Report, St. Joseph, MO: United States Animal Health Association

Frost CC (1993) Four centuries of changing landscape patterns in the longleaf pine ecosystem. Tall Timbers Fire Ecology Conference 18:17-44

Gloster J, Donaldson AI, Hough MN (1984) Analysis of a series of outbreaks of Aujeszky's disease in Yorkshire in 1981-82: the possibility of airborne disease spread. Veterinary Record 114(10):234-239 
Hahn EC, Page GR, Hahn PS, Gillis KD, Romero C, Annelli JA, Gibbs EP (1997) Mechanisms of transmission of Aujeszky's disease virus originating from feral swine in the USA. Veterinary Microbiology 55:123-130

Kristensen CS, Botner A, Takai H, Nielsen JP, Jorsal SE (2004) Experimental airborne transmission of PRRS virus. Veterinary Microbiology 99:197-202

National Pork Producers Council [NPPC] (2009) NPPC economic testimony. Testimony before the U.S. House Committee on Agriculture Subcommittee on Livestock Dairy and Poultry, Oct 22, 2009, Washington, DC

Schoenbaum MA, Freund JD, Beran GW (1991) Survival of pseudorabies virus in the presence of selected diluents and fomites. Journal of the American Veterinary Medical Association 198(8):1393-1397

United States Animal Health Association [USAHA] (2004) All 50 states now free of pseudorabies in swine, http://www.usaha. org/news/pr/2004/p04pseud.txt. Accessed 22 September 2010
United States Department of Agriculture/Animal Plant Health Inspection Service [USDA/APHIS] (2007a) Pseudorabies state status map, www.aphis.usda.gov/animal_health/animal_dis_spec/ swine/images/pseu_st_status_map.jpg. Accessed 28 December 2010

United States Department of Agriculture/Animal Plant Health Inspection Service [USDA/APHIS] (2007b) Brucellosis state status map, www.aphis.usda.gov/animal_health/animal_dis_ spec/swine/images/br_status_map.jpg. Accessed 28 December 2010

Wood GW, Barrett RH (1979) Status of wild pigs in the United States. Wildlife Society Bulletin 7:237-246 